\title{
Dark cutting in large ruminants: Effect of management and environmental factors
}

Alarcón-Rojo, Alma ${ }^{1}$, Mota-Rojas, Daniel ${ }^{2}$; García-Galicia, Iván ${ }^{1}$; Cruz-Monterrosa, Rosy ${ }^{3}$; Ramírez-Bribiesca, Efrén ${ }^{4}$; Olmos-Hernández, Adriana ${ }^{5}$; Guerrero-Legarreta, Isabel ${ }^{6^{*}}$

\begin{abstract}
${ }^{1}$ Universidad Autónoma de Chihuahua, Facultad de Zootecnia y Ecología. ${ }^{2}$ Universidad Autónoma Metropolitana, Unidad Xochimilco. Neurofisiología del Estrés. Comportamiento y Bienestar de los Animales de Granja. ${ }^{3}$ Universidad Autónoma Metropolitana, Unidad Lerma Edo. de México. Dpto. Ciencia de los Alimentos. ${ }^{4}$ Colegio de Postgraduados. Programa de Ganadería. Texcoco Edo. de México. ${ }^{5}$ Instituto Nacional de Rehabilitación. "Luis Guillermo Ibarra Ibarra" (INRLGII), Secretaría de Salud (SSA), México. ${ }^{6}$ Universidad Autónoma Metropolitana-Unidad Iztapalapa, Departamento de Biotecnología, México.
\end{abstract}

*Autor de correspondencia: isabel_guerrero_legarreta@yahoo.com

\begin{abstract}
Objective: This review analyzes the scientific findings on the main management and environmental factors that increase the incidence of dark cuts in the carcass of water buffalo and bovine of the Bos genus.

Design/methodology/approach: Scientific articles were obtained from CAB Abstracts, Pubmed, Scopus and Google Scholar databases. The primary search was carried out on the following keywords: Antemortem stress and handling dark cut, transport, antemortem rest, fasting prior to sacrifice. Detailed searches were subsequently carried out on each species.

Results: There are various stressors in handling and pre-slaughter procedures in ruminants. Stress in animals causes bodily injury and affects the quality of the meat, increasing dark cutting in the carcass

Findings/conclusions: Management practices must be improved in the pre-slaughter stages, animal welfare must be ensured, and stressors must be avoided or reduced. These benefits will help to increase the level of welfare of the animals and will avoid economic losses, due to the presence of dark cutting in the carcass.
\end{abstract}

Keywords: Bubalus bubalis, ante-mortem handling, river buffalo, dark cutting, transport, lairage, beef.

\section{INTRODUCTION}

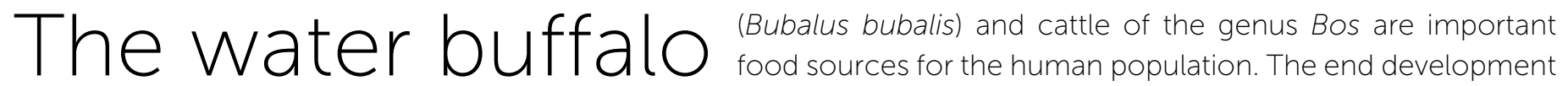
of these animals can occur through fattening in feedlot or grazing. When the animals reach mature body weight, they are shipped, transported, and taken to the slaughterhouse, during slaughter the animals suffer from stress caused by various external factors thus affecting meat quality (Mota-Rojas et al., 2010a,b).

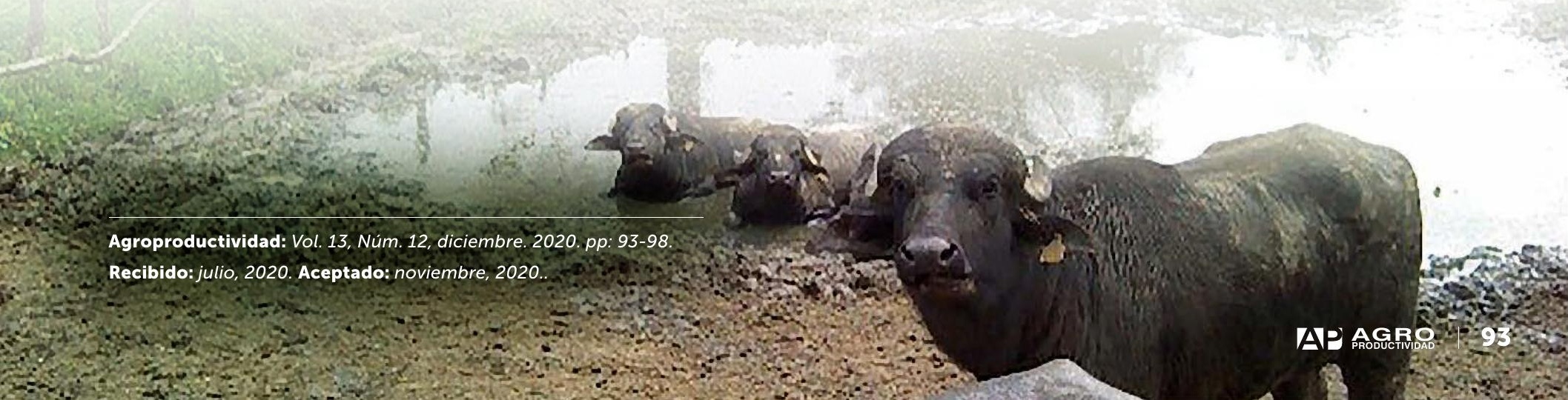


Water buffaloes are valued for their production, disease resistance, longevity, fertility, and meat quality (Macedo, 1999; Sheikh, 2002; Mora-Medina et al., 2019; Bertoni et al., 2019; Hoogesteijn and Hoogesteijn, 2008; GuerreroLegarreta et al., 2020). These animals have better rearing advantages than Bos cattle, for example, they are adapted to the hot and humid regions of muddy and swampy lands of the tropics (Sheikh, 2002; Bertoni et al., 2019; Guerrero-Legarreta et al., 2019a; Mota-Rojas et al., 2019a, b). Although, the appreciation of buffalo meat varies between countries and regions. In some Asian and European countries, buffaloes are marketed at lower prices than cattle, livestock companies implement sales prices and consequently, the productive interest of farmers is limited (Hoogesteijn and Hoogesteijn, 2008; Guerrero-Legarreta et al., 2019b).

The handling and transport of finished animals for meat production, commonly suffer from stress, detracting from their welfare and inducing causes of shrinkage of the carcass, presence of the dark cut in the meat and damage to the carcass due to injuries or bruises (Chandra and Das, 2001ab; Guerrero-Legarreta et al., 2002; Alarcón-Rojo and Duarte-Atondo, 2006; GuerreroLegarreta and Totosaus, 2006; Mota-Rojas et al., 2010a, b; Guerrero-Legarreta et al., 2019b). In reference to beef (Bos), a pH of 6.0 in $24 \mathrm{~h}\left(\mathrm{pH}_{24}\right)$ after slaughter, causes a poor quality of meat. Therefore, becoming undesirable for consumption creating economic losses (Mach et al., 2008). For example, the meat industry in Spain penalizes the price of carcasses with discounts between 30 and $60 \%$, when the $\mathrm{pH}$ of the meat is greater than 5.8 (Mach et al., 2008). Dark firm dry meat (DFD) occurs when the final $\mathrm{pH}$ (measured in 12-48 h) post-mortem is $\geq 6$ (Apple et al., 2005; Warris, 2000). The term DFD is most commonly used in pork meat, so when it occurs in beef, the term assigned is "dark cutting" (Prince et al., 1994; Southern et al., 2006). Beef with a $\mathrm{pH}_{24}$ greater than 6.0 has a dark red color (Mach et al., 2008; Pérez-Linares et al., 2006), there is deterioration in tenderness, the water holding capacity increases (dry) and lower palatability with firmer texture, increases light absorption, microbial growth, unpleasant odor and less uptake of curing salts (Grandin, 1997; Mach et al., 2008; Prince et al., 1994; Alarcón-Rojo and Janacua-Vidales, 2010).

The consumer classifies dark cutting as old meat (PérezLinares et al., 2008; Guerrero-Legarreta et al., 2020; Cruz-Monterrosa et al., 2020). The increase in $\mathrm{pH}_{24}$ is due to the decrease in glycogen pre-slaughter, caused by the physical and psychological stress that occurs in the animals before slaughter. The various stressors involved are the long transport times given from the farm to the slaughter plant, the time the animal waits to enter the slaughterhouse, the climatic conditions and the social breakdown (Schaefer et al., 2001; Önenç, 2004; Ferguson and Warner, 2008; Mach et al., 2008). However, glycogen levels also vary widely at slaughter, depending on the amount of feed consumed, body weight, nutritional status, muscle type, fiber type, muscle buffer capacity, gender, breed type and temperament (Ferguson and Warner, 2008; Mach et al., 2008). Additionally, the handling of the buffalo is more difficult than the cattle, it requires more personnel and time for the activities of loading, confinement, herding, movement, unloading and in the waiting pens for slaughter. Management of water buffalo must have an adequate balance in the truck to avoid injuries (Chandra and Das, 2001).

Most meat-producing countries report annual frequencies of dark cutting meat from 3 to 22\% (PérezLinares et al., 2008). The UK reports a $10 \%$ incidence of dark cutting. The United States reports 4\% (Warris, 2003, Pérez-Linares et al., 2006). Spain (Mach et al. 2008) and northern Mexico (Pérez-Linares et al. 2006) report incidences of dark cutting of 13 and $9 \%$, respectively. The causes of stress are associated with high ambient temperatures, body efforts and high arousal after slaughter (Prädl et al., 1994).

This review analyzes the environmental and management factors that influence dark cutting in water buffalo and cattle (Figure 1, 2). The fasting period, duration of transport, transport conditions and environmental factors, among others, are described.

\section{Environmental and management factors that influence the presence of dark cutting}

Buffalo and cattle can be stressed by hunger, thirst, fatigue and injuries (Ferguson and Warner, 2008; Grandin, 1997; Mach et al., 2008; Mota-Rojas et al., 2019a,b,c). The presence of dark cutting implies animal stress and inadequate conditions before and during slaughter (Grandin, 1997; Mota-Rojas et al., 2010a,b). Factors that induce chronic stress include long periods without food consumption (prolonged fasting), fatigue caused by long periods of transport, fights between animals from different herds when boarding the truck (Silva et al., 1999; Grandin, 1997; Warris, 2000; Alarcón- 
Rojo and Janacua-Vidales, 2010; Pérez-Linares et al., 2008) and/or poor handling during unloading. All these factors cause physical exhaustion (Kent and Ewbank, 1983; Grandin, 1997; Mounier et al., 2006; Ferguson and Warner, 2008; Jeleníková et al., 2008; Pérez-Linares et al., 2008) and have a negative effect in meat quality (Broom, 2003; Mounier et al., 2006; AlarcónRojo and Janacua-Vidales, 2010).

\section{Effect of fasting}

Perhaps fasting in ruminants has lower adverse effects than in other species, because the rumen acts as a reservoir of nutrients and the production of volatile fatty acids is a constant source of energy (Gallo and Tadich 2005). However, the loss of energy reserves causes depletion of liver and muscle glycogen, inducing problems of browning of the meat in the postmortem period (Ferguson and Warner, 2008). Hargreaves et al. (2004) mentions an increase in dark cutting, when the steers were transported without rest for $24 \mathrm{~h}$ while fasting. Animal transport must be programmed, from the moment they arrive at the truck until they are housed in the pens of the slaughterhouse, considering rest periods during the trip. Rest activities for $16 \mathrm{~h}$ and fasting for $24 \mathrm{~h}$ in animals induces a decrease in $\beta$-HBA (Tadich et al., 2005; Gallo and Tadich, 2005). Food deprivation in animals must be managed properly to prevent adverse effects on meat quality. The cited authors conclude that good quality meat can be achieved when resting times are given, before slaughtering the animals.

\section{Effect of climatic conditions}

Adverse seasonal conditions enhance stress in meatproducing animals, cattle are more sensitive to a hotter environment than to cold temperatures, especially when there are sudden changes in temperature (Kadim et al., 2004). Kreikemeier et al. (1998) cite that the dark cutting percentages were more common in the months of October (0.43\%) to February (0.69\%). Likewise, Grandin (1992 and 1993) reported a higher percentage of dark cutting in animals raised in very cold climates and with high rainfall, due to loss of body heat and shivering.

\section{Effect of transport}

Animal stress caused by transport is due to the lack of resting times, lack of food or water, exaggerated noises, fatigue, sudden changes in temperature, accelerated movements of the truck and space restrictions (Ferreira
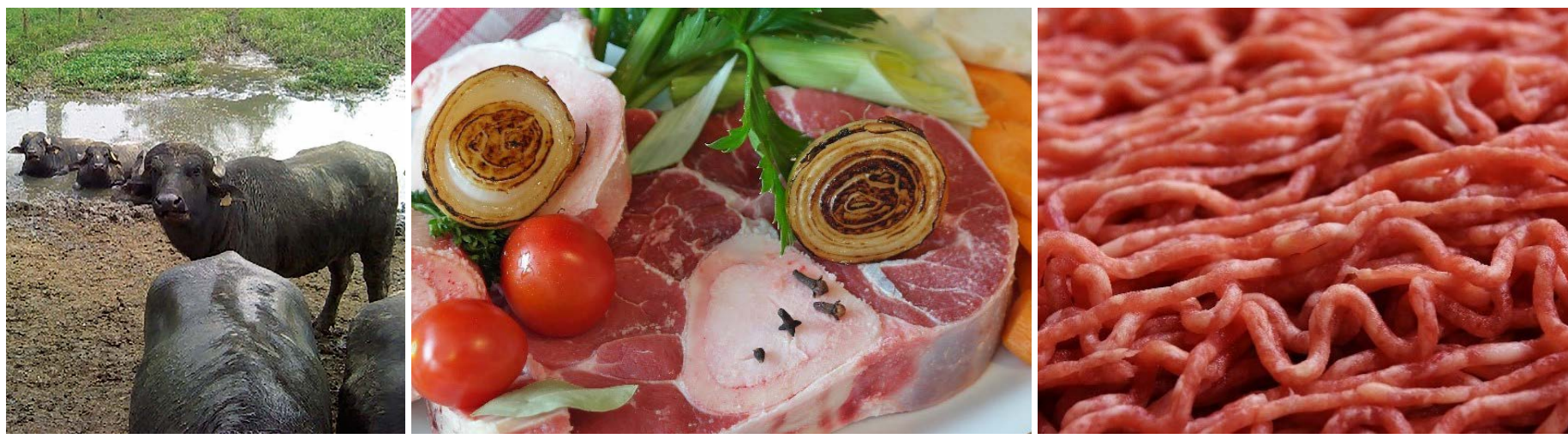

Figure 2: Water buffalo (Bubalus bubalis) and its commercial meat. 
et al., 2006; Gallo, 1994; Hargreaves et al., 2004; Gallo and Tadich 2005).

The time of transfer of animals from the place of breeding to the slaughterhouse should be from 1 to $48 \mathrm{~h}$; if the time is longer, the quality of the carcass and the meat is affected. Losses are particularly caused in live weight, carcass yield and quality grade, appearing dark cutting (Schaefer et al., 2001). Gallo and Tadich (2005) report that the muscular $\mathrm{pH}$ of the steers was not affected when the transport of the animals was less than $16 \mathrm{~h}$ from the corral to the slaughterhouse, and when resting periods before slaughter were less than $16 \mathrm{~h}$. In the case of the water buffalo, Zava (2011) mentions that transport for more than $700 \mathrm{~km}$ causes a loss of 7 and $9 \%$ of their body weight. Also Pérez-Linares et al. (2006) indicate that the arrival of the animals to the truck for more than 35 minutes, with temperatures above $16{ }^{\circ} \mathrm{C}$, caused the damage of dark cutting.

\section{Effect of charge density}

Animal load density during transport affects the levels of some hematic variables (Knowles, 1999; Gallo and Tadich 2005). Tadich et al. (2003b) evaluated the densities of 400 vs. $500 \mathrm{~kg} / \mathrm{m}^{2}$ on some blood metabolites, indicating that the higher density increased cortisol, glucose and creatine kinase. Cortisol and $\mathrm{CK}$ levels remained high until 12 h of animal rest, while the glucose level did not change.

The effect of prolonged transport stress and fasting in sheep also increased blood cortisol content, unlike animals with shorter transportation times (Gallo and Tadich 2005). Similar results in cattle report high glucose and $\mathrm{CK}$ when they were transported in the truck without offering feed on arrival (Tadich et al., 2003b). In Chile, the main risk factors that induce dark cutting is the relationship between fasting and transportation times (Amtmann et al., 2004, Gallo and Tadich 2005). Consequently, the animals should avoid prolonged transportation and long waits until slaughter.

\section{Behavior of the water buffalo during transport}

Chandra and Das (2001a) cite previous routines that should be considered before transporting water buffalo to the slaughterhouse. In Asia, nonproductive animals are transferred to the place-sale, then butchers buy the animals and transport them by trucks to the slaughterhouse (Bertoni et al., 2019). On the other hand, a study carried out with 100 buffalos, divided into ten different transport routes with distances of 20 and $40 \mathrm{~km}$ for 30 minutes. The researchers recorded the activities of the animals on the moving truck. The results of clinical signs that buffaloes presented during the trip were: Ocular congestion, tearing, nasal discharge, signs of stress and fear in buffalo. During the transport route, some animals changed their orientation and placed themselves in a parallel, perpendicular or diagonal position inside the truck. Subsequently, 14 buffaloes changed their initial orientation from parallel to perpendicular or diagonal, there was loss of balance in 80 animals, the curves of the road and speed of the truck caused stress in the animals. The same authors reported ocular congestion lesions (52 animals), nasal discharge (13 animals) and salivation (4 animals). During the trip, urination of the animals was observed in 55 animals, only 20 animals urinated twice, 6 animals three times and 21 buffalo defecated. The high frequency of urination and defecation recorded in animals is an indicative sign of fear (Chandra and Das, 2001a).

\section{Presence of injuries and well-being of the buffalo during transport}

Chandra and Das (2001b) reported injuries to water buffalo during short movements in India. Bruises were considered injuries of interest in the body, sometimes there is blood secretion in the surrounding areas, due to the rupture of blood vessels. During slaughter, the authors used the Australian scoring system to classify animal carcass bruises. They reported 244 bruises of different categories in the 100 buffalo. Small-deep bruises were the most common (59.0\%), then medium bruises (19.3\%), small (9.8\%), medium-deep (6.1\%) and intense (5.7\%). Many bruises were observed in the hind limbs (43.4\%), the abdomen and upper region (21.3\%), the shoulder, neck and back (16.0\%) and the perianal region (11.1\%). The skin was opened in $10 \%$ of traumatic injuries, while the muscle tissues were affected in 90\%. Consequently, the economic losses were considerable due to trauma, with the removal of the damaged tissue in the post-mortem canal. Most of the damaged tissues were attributed to improper handling of the animals during loading and unloading and the fall of the animals, caused by mishandling the sudden braking of the truck.

\section{Rest times in the animals}

The resting places should be the least stressful for the animals. The stress factors cause physiological disorders in the animals and the carcass with high $\mathrm{pH}$ limits vacuum packaging, there is rapid deterioration, the carcass yields and the price of meat decreases (Almonacid, 2003; Gallo and Tadich 
2005). Pipek et al. (2003) mentioned that the incidence of DFD can be reduced when the animals are housed in individual pens, improving the quality of the meat $\left(\mathrm{pH}_{24}\right.$ and reflectance), contrary to when several animals are put in a pen. Pérez-Linares et al. (2008) observed that resting the animals inside the pen for 12 and $18 \mathrm{~h}$ was not enough to reduce stress. On the other hand, Hargreaves et al. (2004) mentioned benefits with the increase of resting time, reducing stress and the $\mathrm{pH}$ of the meat. The cited authors suggest resting times should be greater than $24 \mathrm{~h}$ in the pen. This condition improves glycogen reserve, there is less muscle glycolytic activity, decreases post-mortem lactic acid formation (Hargreaves et al., 2004), and undesirable characteristics in meat are prevented (Prince et al., 1994).

\section{CONCLUSION}

The appearance of dark cutting is directly related to the amount of muscle and liver glycogen thus decreasing the quality of the meat. Animals cannot remain for a long time without eating food and must be handled properly during the antemortem period. Stress periods in buffaloes and cattle must be kept to a minimum, avoiding the use of energy reserves and the increase in $\mathrm{pH}$ of the meat. Good practices of handling training on ruminant welfare must be applied to avoid suffering prior and during to slaughter.

\section{REFERENCES}

Alarcón-Rojo, A. D., Duarte-Atondo, J. O. (2006). Ciencia y tecnología de carnes. In Hui, Y. H., Guerrero, L. I., Rosmini, R. M. (Ed.), Ciencia y Tecnología de Carnes. México. Limusa.

Alarcón-Rojo, A. D., Janacua-Vidales, H. (2010). Alteración de las reacciones enzimáticas post-mortem en carnes PSE y DFD. In Mota Rojas, D., Guerrero-Legarreta, I., Trujillo-Ortega, M.E. (Ed.), Bienestar Animal y Calidad de la Carne: enfoques bioquímicos y experimentales (pp. 287-299). BM Editores. México.

Amtmann, V.; Gallo, C. \& Van Schaik, G. (2004). Factores de riesgo asociados a la presentación de corte oscuro en bovinos. XIII Congreso Chileno de Medicina Veterinaria. Valdivia, Chile. 4-6 de noviembre

Apple, J. K., Kegley, E. B., Galloway, D. L., Wistuba, T. J., \& Rakes, L. K. (2005). Duration of restraint and isolation stress as a model to study the dark-cutting condition in cattle1,2 Journal of Animal Science, 83(5), 1202-1214. https://doi. org/10.2527/2005.8351202x

Bertoni, A., Alvarez-Macias, A., \& Mota-Rojas, D. (2019). Productive performance of buffaloes and their development options in tropical regions. Soc Rur Prod Med Amb, 19, 59-80.

Broom, D. M. (2003). Transport stress in cattle and sheep with details of physiological, ethological and other indicators. DTW. Deutsche Tierarztliche Wochenschrift, 110(3), 83-89.

Chandra, B. S., \& Das, N. (2001a). The handling and short-haul road transportation of spent buffaloes in relation to bruising and animal welfare. Tropical Animal Health and Production, 33(2). 155-163. https://doi.org/10.1023/A:1005242815540

Chandra, B. S., \& Das, N. (2001b). Behaviour of Indian river buffaloes (Bubalus bubalis) during shorthaul road transportation. Veterinary Record, 148(10), 314-315. https://doi.org/10.1136/vr.148.10.314

Cruz-Monterrosa, R., Mota-Rojas, D., Ramírez-Bribiesca, E., MoraMedina P., Guerrero-Legarreta I. 2020. Scientific Findings on the Quality of River Buffalo Meat and it's Prospects for Future Studies. Journal of Buffalo Science, 9, 170-180. DOI: https:// doi.org/10.6000/1927-520X.2020.09.18

Ferguson, D. M., \& Warner, R. D. (2008). Have we underestimated the impact of pre-slaughter stress on meat quality in ruminants? Meat Science, 80(1), 12-19. https://doi.org/10.1016/j. meatsci.2008.05.004

Ferreira, G. B., Andrade, C. L., Costa, F., Freitas, M. Q., Silva, T. J. P., \& Santos, I. F. (2006). Effects of transport time and rest period on the quality of electrically stimulated male cattle carcasses. Meat Science, 74(3), 459-466. https://doi.org/10.1016/j. meatsci.2006.04.006

Gallo C. (1994). Efecto del manejo pre y post faenamiento en la calidad de la carne. Serie Simposios y Compendios de La Sociedad Chilena de Producción Animal, 2, 27-47

Gallo, C., \& Tadich, N. (2005). Transporte terrestre de bovinos: Efectos sobre el bienestar animal y la calidad de la carne. Agro-Ciencia, 21(2), 37-49

Grandin, T. (1993). Behavioral agitation during handling of cattle is persistent over time. Applied Animal Behaviour Science, 36(1) 1-9. https://doi.org/10.1016/0168-1591(93)90094-6

Grandin, T. (1997). Assessment of Stress during Handling and Transport Journal of Animal Science, 75(1), 249-257. https://doi. org/10.2527/1997.751249x

Guerrero Legarreta, I., Ponce, E., Pérez, M. I. (2002). Curso Práctico de Tecnología de Carnes y Pescado. Universidad Autónoma Metropolitana-Unidad Iztapalapa. México D.F.

Guerrero Legarreta, I. \& Totosaus, A. (2006). Propiedades funcionales de la carne. In Y., Hui, I. Guerrero Legarreta (Ed.), Ciencia y Tecnología de Carnes (p. 235). Limusa.

Guerrero-Legarreta, I., Napolitano, F., Mota-Rojas, D., Cruz-Monterrosa, R., Mora-Medina, P., \& Berdugo-Gutiérrez J. (2019a). The Water Buffalo: versatile, rustic and sustainable as a meat producer Agro Meat, 1-10.

Guerrero-Legarreta, I., García-Galicia, I., Ramírez-Bribiesca, R., MotaRojas, D., Cruz-Monterrosa, R., Olmos-Hernández, A., \& Alarcón-Rojo, A. D., (2019b). Capítulo 21. Factores que afectan la calidad de la carne del búfalo de agua, bovino del género Bos. In: Guerrero-Legarreta, I., Napolitano, F., Mota-Rojas, D., \& Orihuela, A. (Ed.), El búfalo de agua en las Américas. México. BM Editores

Guerrero-Legarreta, I., Napolitano, F., Cruz-Monterrosa, R., MotaRojas, D., Mora-Medina, P., Ramírez-Bribiesca, E., Bertoni, A. Berdugo-Gutiérrez, J., \& Braghieri, A. (2020). River buffalo meat production and quality: sustainability, productivity, nutritional and sensory properties. Journal of Buffalo Science, 9, 159-169 https://doi.org/10.6000/1927-520X.2020.09.17

Hargreaves, A., Barrales, L., Peña, I., Larraín, R., \& Zamorano, L. (2004) Factores que Influyen en el pH Ultimo e Incidencia de Corte Oscuro en Canales de Bovinos. Ciencia e Investigación Agraria, 31(3), 155-166 
Hoogesteijn, R., \& Hoogesteijn, A. (2008). Conflicts between cattle ranching and large predators in Venezuela: could use of water buffalo facilitate felid conservation? Oryx, 42(01). https://doi. org/10.1017/S0030605308001105

Jeleníková, J., Pipek, P., \& Staruch, L. (2008). The influence of ante-mortem treatment on relationship between $\mathrm{pH}$ and tenderness of beef. Meat Science, 80(3), 870-874. https://doi. org/10.1016/j.meatsci.2008.04.004

Kadim, I. T., Mahgoub, O., Al-Ajmi, D. S., Al-Maqbaly, R. S., Al-Mugheiry, S. M., \& Bartolome, D. Y. (2004). The influence of season on quality characteristics of hot-boned beef $\mathrm{m}$. longissimus thoracis. Meat Science, 66(4), 831-836. https://doi.org/10.1016/j. meatsci.2003.08.001

Kent, J. E., \& Ewbank, R. (1983). The effect of road transportation on the blog constituent and behavior of calves. I. Six months old. The British veterinary journal, 139, 228-235

Knowles, G. (1999). A review of the road transport of cattle. Veterinary Record, 144(8), 197-201. https://doi.org/10.1136/ vr.144.8.197

Kreikemeier, K. K., Unruh, J. A., \& Eck, T. P. (1998). Factors affecting the occurrence of dark-cutting beef and selected carcass traits in finished beef cattle. Journal of Animal Science, 76(2), 388. https://doi.org/10.2527/1998.762388x

Macedo, M. C. M. (1999). Degradacxao de pastagens: conceitos e metodos de recuperacxao. Simposio Sustentabilidade Da Pecuaria de Leite No Brasil, 137-150.

Mach, N., Bach, A., Velarde, A., \& Devant, M. (2008). Association between animal, transportation, slaughterhouse practices, and meat $\mathrm{pH}$ in beef. Meat Science, 78(3), 232-238. https://doi. org/10.1016/j.meatsci.2007.06.021

Mora-Medina, P., Mota-Rojas, D., Álvarez, A., Flores, K., Reyes, B., Torres, F., Bertoni, A., \& Guerrero-Legarreta, I. (2019). Capítulo 18. La huella ambiental en la producción pecuaria. En: El búfalo de agua en las Américas. México. BM Editores.

Mota-Rojas, D., Alarcón-Rojo, A.D., Vázquez GG., Guerrero-Legarreta, I. (2010a). Músculo oscuro firme y seco en bovinos, mecanismos involucrados. In Bienestar animal y calidad de la carne (pp. 271286). BM Editores.

Mota-Rojas, D., Guerrero-Legarreta, I., Trujillo, O. M. E. (2010b). Bienestar animal y calidad de la carne. México. BM Editores.

Mota-Rojas, D., Guerrero-Legarreta, I., Pérez-Álvarez J.A., Rosmini, M. Napolitano, F., Ghezzi, M., Fernández-López, J. Braghieri, A., Viuda, M., Bragaglio, A., \& Mora-Medina, P. (2019a). Capítulo 1. La carne de búfalo de agua en las Américas: retos y oportunidades. En: Guerrero-Legarreta I, Napolitano F, MotaRojas D. \& Orihuela A. (Ed.). El búfalo de agua en las Américas (2da. Eds.). México. BM Editores.

Mota-Rojas, D., De Rosa, G., Mora-Medina, P., Braghieri, A., \& GuerreroLegarreta, I. Napolitano F. (2019b). Dairy buffalo behaviour and welfare from calving to milking. CAB Reviews: Perspectives in Agriculture, Veterinary Science, Nutrition and Natural Resources, 14(035). https://doi.org/10.1079/PAVSNNR201914035

Mota-Rojas, D., Álvarez, A., Bertoni, A. Molina S., José, N., López, G., Mora, P., Guerrero, I., \& Napolitano, F. (2019c). Capítulo 8. La importancia de los animales en labores rurales: tracción, transporte y carga. In Guerrero-Legarreta, I., Napolitano, F., Mota-Rojas, D., Orihuela, A. (Ed.). El búfalo de agua en las Américas (2da. Eds.). México. BM Editores.
Mounier, L., Dubroeucq, H., Andanson, S., \& Veissier, I. (2006). Variations in meat $\mathrm{pH}$ of beef bulls in relation to conditions of transfer to slaughter and previous history of the animals1. Journal of Animal Science, 84(6), 1567-1576. https://doi. org/10.2527/2006.8461567x

Önenç, A. (2004). Dark Cutting Incidence in Holstein Friesian, Brown Swiss and Eastern Anatolian Red Cattle Slaughtered Under Turkish Commercial Slaughter Conditions. Pakistan Journal of Biological Sciences, 7(1), 96-99. https://doi.org/10.3923/ pjbs.2004.96.99

Pérez-Linares, C., Figueroa-Saavedra, F., \& Barreras-Serrano, A. (2006). Relationship between management factors and the occurrence of DFD meat in cattle. Journal of Animal and Veterinary Advances, 5, 578-581.

Pérez Linares, C., Figueroa-Saavedra, F., \& Barreras-Serrano, A. B. (2008). Management Factors Associated to DFD Meat in Bovine on. Archivos de Zootecnia, 57(220), 545-547.

Pipek, P., Haberl, A., Jeleníková, J. (2003). Influence of slaughterhouse handling on the quality of beef carcasses. Czech Journal of Animal Science, 48(9), 371-378

Prädl, O., Fischer, A., Shmidhofer, T., Sinell, H. (1994). Tecnología e higiene de la carne. Acribia.

Prince, J. F., Schweigert, B. S. (1994). Ciencia de la carne y de los productos cárnicos. Acribia.

Schaefer, A. L., Dubeski, P. L., Aalhus, J. L., \& Tong, A. K. W. (2001). Role of nutrition in reducing antemortem stress and meat quality aberrations. Journal of Animal Science, 79(E-Suppl), E91. https://doi.org/10.2527/jas2001.79E-SupplE91x

Sheik, P. A. (2002). The impact of water buffalo and cattle ranching on the lower Amazon floodplain: an ecological and socioeconomic comparison. PhD thesis, Pennsylvania State University, State College, USA

Silva, J. A., Patarata, L., \& Martins, C. (1999). Influence of ultimate pH on bovine meat tenderness during ageing. Meat Science, 52(4), 453-459. https://doi.org/10.1016/S0309-1740(99)00029-7

Southern, K. J., Rasekh, J. G., Hemphill, F. E., \& Thaler, A. M. (2006). Conditions of transfer and quality of food. Revue Scientifique et Technique (International Office of Epizootics), 25(2), 675-684.

Tadich, N., Gallo, C., Bustamante, H., Schwerter, M., \& van Schaik, G. (2005). Effects of transport and lairage time on some blood constituents of Friesian-cross steers in Chile. Livestock Production Science, 93(3), 223-233. https://doi.org/10.1016/j. livprodsci.2004.10.004

Tadich, N., Gallo, C., Echeverria, R., \& van Schaik, G. (2003). Efecto del ayuno durante dos tiempos de confinamiento y de transporte terrestre sobre algunas variables sanguíneas indicadoras de estrés en novillos. Archivos de Medicina Veterinaria, 35(2). https://doi.org/10.4067/S0301-732X2003000200005

Warriss, P. D. (1990). The handling of cattle pre-slaughter and its effects on carcass and meat quality. Applied Animal Behaviour Science, 28(1-2), 171-186. https://doi.org/10.1016/01681591(90)90052-F

Warris, P. D. (2000). The effects of live animal handling of carcass and meat quality. In Meat Science an introductory text (pp. 131155). CABI Publishing

Zava, M. (2002). Manejo y Bienestar Animal El búfalo doméstico. Orientación Gráfica Editora. 